\title{
A CONSTITUIÇÃO ENTRE A REGULAÇÃO E A EMANCIPAÇÃO: o neoconstitucionalismo e a "ductilização" da estrutura jurídico-política do Estado
}

\section{THE CONSTITUTION BETWEEN THE REGULATION AND THE EMANCIPATION: the neoconstitutionalism and the "ductility" of the legal-political structure of the State}

\author{
IGOR MENDES BuENO \\ Acadêmico do $7^{\circ}$ Semestre do Curso de Direito da Universidade Federal de Santa Maria (UFSM). \\ Bolsista do CNPq - Brasil.
}

Valéria Ribas do Nascimento

Doutora em Direito pela Universidade do Vale do Rio dos Sinos (UNISINOS), com período de pesquisa na Universidade de Sevilha (US); Mestre em Direito Público pela Universidade de Santa Cruz do Sul (UNISC); Graduada em Direito pela

Universidade Federal de Santa Maria (UFSM); Professora Adjunta do Departamento de Direito da UFSM; Advogada; Integrante do Núcleo de Direito Informacional (NUDI) e coordenadora do grupo de pesquisa intitulado "A reconstrução

de sentido do constitucionalismo".

\section{RESUMO}

O trabalho demonstra o caráter histórico e dialético do constitucionalismo. Assim, pretende contribuir para a compreensão da relação entre os ideais políticos emancipatórios e o constitucionalismo em suas diversas fases, mantendo constante diálogo entre os desenvolvimentos teóricos da filosofia política, da teoria do Estado, da sociologia e do Direito Constitucional. Observa-se a crescente materialização da Constituição durante o curso histórico, que explicita seu caráter condensador de uma materialidade institucional permeada de contradições internas que expressam a especificidade do Estado capitalista. Ao final, caracteriza o momento atual da teoria constitucional e sugere, na tese do "direito dúctil", algumas considerações sobre uma possível transformação no seio da estrutura jurídico-política do Estado, capaz de promover uma maior abertura e, ao mesmo tempo, internalização das lutas políticas aos seus aparelhos. Quanto à metodologia, opta-se pela hermenêutica fenomenológica.

Palavras-chave: Constituição, direito dúctil, Estado, estrutura jurídico-política, neoconstitucionalismo.

\begin{abstract}
This paper demonstrates the historical and the dialectical character of the constitutionalism. Therefore, it intends to contribute to the understanding of the relationship between the emancipatory and political ideals and constitutionalism in its various facets, mantaining constant dialogue among the theoretical developments of political philosophy, theory of the State, of Sociology and of Constitutional Law. Throughout history journey, there has been an increasing materialization of the Constitution, fact that explicits its condensing character of an institutional materiality permeated of internal contradictions that express the specificity of the capitalist State. At the end, the study characterizes the current situation in constitutional theory and suggests, among the thesis of the "ductile right," some considerations about a possible transformation within the legal-political structure of the State, capable of promoting greater openness and, at the same time, internalization of the political struggles to their devices. Regarding the methodology, the choice should be phenomenological hermeneutics.
\end{abstract}

Keywords: Constitution, ductile right, neoconstitucionalism, legal-political structure, State. 


\section{SUMÁRIO}

INTRODUÇAO; 1 CONSTITUCIONALISMO E ESTADO NO PROJETO EMANCIPATÓRIO MODERNO; 1.1 A teoria política liberal e o projeto emancipatório moderno; 1.2 Constitucionalismo moderno: do pilar emancipatório à fundação da estrutura jurídico-política do Estado capitalista; 2 CONSTITUIÇÃO E ESTADO COMO PRODUTO DE UM EMBATE TEÓRICO E POLÍTICO; 2.10 desequilíbrio do projeto moderno e a ascensão do ideal emancipatório (classista) das doutrinas sociais do século XIX; 2.2 Estado (e Constituição) como uma condensação material de relações de força; 30 NEOCONSTITUCIONALISMO: PRÁXIS EMANCIPATÓRIA?; 3.1 Ascensão e crise da cidadania social, novos movimentos sociais, globalização e pluralismo; 3.2 Estado constitucional e neoconstitucionalismo: notas gerais; 3.30 direito dúctil: sobre a "ductilização" da estrutura jurídico-política do Estado e a abertura às lutas políticas; CONCLUSÃO; REFERÊNCIAS.

\section{INTRODUÇÃO}

A história da humanidade é sabidamente uma trajetória de coerção e resistência, reação à coerção, ao longo dos séculos - de criação de novas formas de opressão e consequente busca pela liberdade. Esta busca traduz o sentido dos movimentos emancipatórios humanos. A relação íntima entre "liberdade" e "emancipação" se deve ao fato de que emancipar-se pressupõe postar-se em estado de liberdade, rompendo com um estado anterior de opressão, coerção ou simples não-liberdade. Mas o sentido de “liberdade” não é, na teoria política, unívoco e, consequentemente, também não se pode falar em uma só espécie de libertação - as concepções de emancipação e liberdade, portanto, variam em sentido, dependendo do momento histórico e da linha teórica sob análise. Pode-se, portanto, quaisquer que sejam as variantes, estabelecer esta relação direta entre "emancipação" e "liberdade" de tal forma que a concepção dada à última interfere sobremaneira na compreensão da primeira.

Colocada a questão desta forma, não se pode pensar em liberdade ignorando sua antítese, o poder, problematizado e exaustivamente estudado pela ciência política. Sobre isso, a teoria relacional do poder demonstra que o poder é a síntese de uma relação entre dois sujeitos, possuindo estreito vínculo com o conceito de liberdade. Dessa forma, tais conceitos podem ser definidos um pela negação do outro, ou seja, o poder de "A" implica a não-liberdade de “B”, a liberdade de A implica o não-poder de "B"1.

\footnotetext{
1 BOBBIO, Norberto. Estado, governo, sociedade; para uma teoria geral da política. 12. ed., Rio de Janeiro: Paz e Terra, 2005a. p. 78.
} 
0 poder, portanto, não é externo às relações sociais, é sim um corolário destas relações; mais precisamente das relações desiguais de força ${ }^{2}$. Como consequência, os desenvolvimentos teórico-filosóficos de cada época marcam sempre preocupação com a temática do uso, abuso e exploração do poder: da negação (teórica ou política) de uma específica forma de poder, surge a necessidade da emancipação, do rompimento das amarras que prendem o sujeito àquela objetividade negada.

Como bem explicitou Nicola Matteucci, o Constitucionalismo é a técnica da liberdade ${ }^{3}$. O constitucionalismo é, portanto, no âmbito das ciências política e jurídica, o movimento e a técnica (respectivamente) pela qual se asseguram determinados direitos e garantias ao indivíduo e à sociedade, e impõe ao Estado o dever de não os violar. Pode-se dizer que o fenômeno constitucional é um “movimento" em dois sentidos, já que é tanto produto de um movimento de luta pela liberdade, quanto também, se movimenta no transcorrer histórico, pois apresenta diversas fases de desenvolvimento conforme o momento em exame.

Se o constitucionalismo possui esse estreito vínculo com a liberdade, por certo que deve na mesma medida ter relação com a emancipação humana. Tal é o objetivo geral deste trabalho: compreender a relação entre os ideais emancipatórios ao longo do curso histórico recente e os diferentes momentos do constitucionalismo. Caberá então apontar algumas características da fase atual do constitucionalismo (o chamado "neoconstitucionalismo"), procurando compreender qual é o seu sentido para os ideais emancipatórios; se pode o constitucionalismo contemporâneo oferecer bases sólidas à crítica e transformações sociais em busca da emancipação humana e, em se conferindo tal assertiva, aferir, mesmo que de forma preliminar, em que medida tais transformações são facilitadas pelos novos apontamentos constitucionais. Nesse sentido, é demonstrado, em último grau, o caráter dialético do constitucionalismo e, consequentemente, da constituição, enquanto documento instituidor da específica materialidade institucional do Estado.

Para tanto, será travado um diálogo entre alguns dos mais recentes estudos no âmbito do Direito Constitucional - nutrindo-se principalmente das obras de Gustavo Zagrebelsky e Alfonso de Julios-Campuzano -, a sociologia e determinadas categorias desenvolvidas no âmbito da filosofia política. Assim, será identificado, a partir da abordagem do sociólogo Boaventura de Sousa Santos, três momentos emancipatórios que se manifestaram nas democracias ocidentais a

\footnotetext{
${ }^{2}$ POULANTZAS, Nicos. O Estado, o poder, o socialismo. 4. ed., São Paulo: Graal, [1978] 2000. p. 150. ${ }^{3} \mathrm{MATTEUCCI}$, Nicola. Constitucionalismo. In: BOBBIO, Norberto. MATTEUCCI, Nicola. PASQUINO, Gianfranco (org). Dicionário de Política. 11. ed., Brasília: Editora UnB, 1998. p. 247.
} 
partir do momento de ruptura com o período pré-moderno e empreender-se-á a devida relação com as formações estatais e os modelos de Constituição/constitucionalismo formados. Anote-se que, neste intento, utilizar-se-á a diferenciação estabelecida por Gustavo Zagrebelsky entre as categorias Estado de direito (nas tradicionais formas liberal e social) e Estado constitucional, referindo-se esta última aos modelos de Estado das sociedades pluralistas atuais.

Também, será essencial a este estudo utilizar algumas importantes contribuições formuladas pelo filósofo Nicos Poulantzas - na forma de categorias teórico-políticas - na tentativa de compreender o tipo de Estado formado após a queda do antigo regime. É forçoso advertir que, dessa forma, será necessário trabalhar com tipos ideais e teorias gerais - um grau de abstratividade que, no entanto, apesar da inegável distância relativa entre teoria e prática, não afasta a importância do presente trabalho para o auxílio da compreensão dos fenômenos constitucionais particulares no tempo/espaço em que se desenvolvem.

Ainda que a pesquisa indique a utilização de método de abordagem dialético, em vertentes conservadoras, não é possível a interpretação sem a compreensão, uma vez que, para interpretar, antes é preciso compreender. Por isso, opta-se por não fazer uso de métodos tradicionais advindos do esquema lógico-formal da ciência clássica, já que esses tendem a se fechar à realidade. Assim, entende-se que a postura fenomenológica-hermenêutica é mais adequada aos objetivos desta proposta de pesquisa. Fenomenológica, porque entende a subjetividade como parte da realidade social, sendo o sujeito ator que estabelece com a sociedade íntima relação e, a partir daí, promove a interpretação da vida cotidiana. E, hermenêutica, pois parte da tese de que a experiência sensível é em si mesma um processo interpretativo, a partir do qual se pretende a compreensão de todos os matizes da comunicação humana.

Vale afirmar, também, que a discussão ora apresentada relaciona-se com problemáticas já trabalhadas em projetos do CNPq/CAPES, no interior do Grupo de Pesquisa da Universidade Federal de Santa Maria (UFSM/RS), denominado "A reconstrução de sentido do constitucionalismo", este com patrocínio do Edital Chamada MCTI/CNPq/MEC/CAPES - n. ${ }^{\circ}$ 07/2011. 


\section{CONSTITUCIONALISMO E ESTADO NO PROJETO EMANCIPATÓRIO MODERNO}

\subsection{A teoria política liberal e o projeto emancipatório moderno}

O liberalismo lançou, na sua forma clássica, as bases para a formação das primeiras Constituições. Foi edificado como o pensamento que por excelência estabeleceu limites aos poderes e funções do Estado - em contraposição ao Estado absolutista durante a modernidade e, já na contemporaneidade (sob a forma do novo liberalismo), ao Estado social, surgido em meados do séc. $X X^{4}$.

A tradição liberal, desenvolvida a partir da transição entre os séculos XVII e XVIII, tem como pressuposto básico para o estudo do Estado o desenvolvimento da doutrina dos direitos do homem elaborada pelas construções teóricas do jusnaturalismo, segundo as quais o homem possui direitos (à vida, à propriedade, à segurança, etc.) inerentes a sua condição humana, que podem ser compreendidos através do exercício racional, e que não podem ser coercitivamente tolhidos pela vontade arbitrária de outrem. Toda essa conjuntura foi a base de uma verdadeira revolução no pensamento político, promovida pelo desenvolvimento da ideia do indivíduo como centro dos estudos sobre a sociedade e o Estado; o indivíduo passa a ser entendido como anterior à sociedade (construção viabilizada pelas teorias contratualistas) - uma evidente contradição com a então dominante visão organicista de base aristotélica (da sociedade anterior ao indivíduo).

O elemento central que interessa na contribuição do que representa "emancipação" à tradição liberal é o conceito de "liberdade individual" forjado por essa matriz. A liberdade individual possui íntima relação com a chamada "liberdade negativa”, pela qual se entende "a situação na qual um sujeito tem a possibilidade de agir sem ser impedido, ou de não agir sem ser obrigado por outros"5. Mais uma vez Bobbio esclarece a importante relação entre liberdade individual e liberdade negativa:

Quando tomamos em consideração a liberdade negativa, o sujeito histórico a que nos referimos é geralmente o indivíduo singular [...]. As liberdades civis, protótipo das liberdades negativas, são liberdades individuais, isto é, inerentes ao indivíduo singular: com efeito, são historicamente o produto das lutas pela

\footnotetext{
${ }^{4}$ BOBBIO, Norberto. Liberalismo e democracia. 6. ed., São Paulo: Brasiliense, 2005b. p. 7.

${ }^{5}$ BOBBIO, Norberto. Igualdade e liberdade. Rio de Janeiro: Ediouro, 1996. p. 48.
} 
defesa do indivíduo, considerado ou como pessoa moral (e, portanto, tendo um valor em si mesmo) ou como sujeito de relações econômicas, contra a intromissão de entes coletivos como a Igreja e o Estado. ${ }^{6}$

Os esforços teóricos do liberalismo em torno do desenvolvimento da ideia de indivíduo e dos direitos individuais provenientes dessa noção de liberdade tiveram, de forma geral, um sentido claro: romper com a ordem política do ancien régime, que impedia o livre desenvolvimento da nova e incipiente configuração da base econômica; das relações econômicas da nascente burguesia. Em outras palavras, o objetivo era emancipar a classe burguesa das amarras políticas de uma ordem estanque e abrir caminho a uma nova objetividade, marcada pelo ideal de inviolabilidade daqueles direitos básicos construídos com auxílio das teorias liberais. Esse rompimento com o status quo então vigente é inserido em um novo projeto de sociedade - empreende-se uma deformação estrutural da sociedade pré-moderna.

O projeto da modernidade, segundo o sociólogo Boaventura de Sousa Santos, é baseado em dois pilares que sustentariam a transformação radical da sociedade pré-moderna e, idealmente, desenvolver-se-iam em equilíbrio; são os pilares da regulação e da emancipação. 0 pilar da regulação seria constituído, assim, por três princípios: (a) o do mercado, baseado nos postulados lockeanos; (b) o do Estado, inscrito no pensamento de Hobbes; e (c) o da comunidade, figurado na teoria de Rousseau. O pilar da emancipação, por outro lado, erige-se sobre "três dimensões da racionalização e secularização da vida coletiva": (a) a racionalidade cognitivo-experimental da ciência e da técnica modernas, (b) a racionalidade moral-prática do direito moderno, e (c) a racionalidade estético-expressiva das artes e literatura modernas. Sobre a articulação idealizada entre esses dois pilares, Boaventura refere que "o equilíbrio pretendido entre a regulação e a emancipação obtém-se pelo desenvolvimento harmonioso de cada um dos pilares e das relações dinâmicas entre eles"7.

Dessa forma, inserido neste contexto da desestruturação do paradigma pré-moderno, acompanhando a ascensão do projeto da modernidade, esteve, como será analisado, o constitucionalismo moderno.

\footnotetext{
${ }^{6}$ Ibid., p. 57.

${ }^{7}$ SANTOS, Boaventura de S. Subjetividade, cidadania e emancipação. In: e o político na pós-modenidade. 11. ed., São Paulo: Cortez, 2006. p. 236. . Pela mão de Alice: o social
} 


\subsection{Constitucionalismo moderno: do pilar emancipatório à fundação da estrutura jurídico-política do Estado capitalista}

Como já fora dito, Matteucci lembra da caracterização do constitucionalismo como uma específica "técnica da liberdade". Dessa forma, continua o autor italiano: "Isto é, a técnica jurídica pela qual é assegurado aos cidadãos o exercício dos seus direitos individuais e, ao mesmo tempo, coloca o Estado em condições de não os poder violar"; e termina referindo, em uma importante passagem, que "se as técnicas variam de acordo com a época e as tradições de cada país, o ideal das liberdades do cidadão continua sendo sempre o fim último: é em função deste que se preordenam e organizam as técnicas"

De fato o movimento constitucional moderno carrega forte influência dos desenvolvimentos da teoria política liberal, por meio de diversas técnicas e métodos provindos destes apontamentos teóricos, que seriam inscritas nas Constituições modernas. Algumas dessas técnicas encontram sua base nos ideais de separação e divisão dos poderes do Estado (seja pela forma da clássica separação de poderes montesquiana, seja por técnicas como a do federalismo) - algumas das primeiras formulações liberais forjadas no intuito de desmembrar o poder do Estado absoluto. Como bem lembra o próprio Matteucci, ao citar Carl Friedrich, "o absolutismo, em qualquer das suas formas, prevê a concentração do exercício do poder; o Constitucionalismo, pelo contrário, prevê que esse exercício seja partilhado"9. Assim, o princípio liberal da separação de poderes, por meio de autores como Locke, Montesquieu e Kant, encontra amparo prático também no movimento constitucional.

Outras ligações do constitucionalismo com a teoria política e jurídica liberal ganham azo na teoria das garantias, formulada por Benjamin Constant e muito influente na França do século XIX, pela fórmula do Estado de Direito (ou Rechtstaat) estabelecida pela doutrina publicística alemã, e pelo princípio do rule of law, forjado na Inglaterra e perpetrado na tradição do common $l a w^{10}$. Apesar de consistirem em técnicas diferentes de garantia dos direitos, estas teorias se revestem do ideal de garantia da liberdade contra o abuso do ente estatal ${ }^{11}$.

Dessa forma, nutrindo-se desses ideais de garantia das liberdades civis, o constitucionalismo moderno se insere no projeto de ruptura com a ordem social e estatal

\footnotetext{
${ }^{8}$ MATTEUCCI, Nicola. op. cit. pp. 247-248.

9 Ibid., p. 248.

${ }^{10}$ Ibid., p. 250-252.

11 Ibid., p. 255; ZAGREBELSKY, Gustavo. El derecho dúctil; Ley, derecho, justicia. 7. ed., Madrid: Editorial Trotta, 2007. p. 25.
} 
formada no contexto do antigo regime. 0 constitucionalismo é inserido assim, pelo menos em um primeiro momento, nas bases da emancipação moderna; e a Constituição torna-se então um estratégico instrumento do projeto emancipatório moderno.

Afirma-se "pelo menos em um primeiro momento" porque a partir deste período percebe-se uma paradoxal transformação relativa no que diz respeito à colocação da Constituição nesse processo - tal transformação é, na verdade, um fato com dois lados aparentemente contraditórios. A Constituição deixa de ser um instrumento potencialmente emancipatório, transformador da sociedade, para caracterizar um documento instituidor e regulador da nova estrutura social formada, que contém ainda os cálculos precisos de transformações pontuais que garantem sua auto-preservação.

Apesar das várias técnicas citadas, a partir das quais o constitucionalismo foi nutrido para a derrubada do poder absoluto, algumas delas foram predominantes nos processos políticos e jurídicos que sucederam àquele período, e constituíram pontos centrais dessa transformação; cite-se aqui o desenvolvimento do modelo de Estado de direito. Gustavo Zagrebelsky já evidenciara isso em sua obra $E l$ derecho dúctil:

El siglo XIX es el siglo del "Estado de derecho" o, según la expresión alemana, del Rechtstaat. [...] No cabe duda que el Estado de derecho ha representado históricamente uno de los elementos básicos de las concepciones constitucionales liberales, aunque no es en absoluto evidente que sea incompatible con otras orientaciones político-constitucionales. ${ }^{12}$

Resta clara, portanto, a relação íntima entre a fórmula do Estado de direito e o constitucionalismo, pelo menos em suas versões tradicionais. Sobre as fontes das quais se nutriu o desenvolvimento da noção de Estado de direito, o professor Alfonso de Julios-Campuzano ainda lembra que:

O Estado de Direito como construção teórica foi iluminado pela ciência alemã do direito público, sob a perspectiva do positivismo jurídico que dominava a Europa do século XIX - especialmente depois das contribuições de Von Habitem e Von Mohl que foram os pais da fórmula Rechtstaat -, seus principais fundamentos teóricos possuem suas raízes no jusnaturalismo racionalista, no contratualismo, na tradição liberal-democrática e nas decisivas contribuições que a ilustração legou à humanidade. ${ }^{13}$

\footnotetext{
${ }^{12}$ ZAGREBELSKY, Gustavo. Op Cit., pp. 21-22.

13 JULIOS-CAMPUZANO, Alfonso de. Constitucionalismo em tempos de globalização. Porto Alegre: Livraria do Advogado, 2009. p. 10.
} 
Dessa forma, o Estado de direito se baseava predominantemente no chamado princípio da legalidade, que elevava a lei como fonte máxima do direito. Na lição de Zagrebelsky, o princípio da legalidade "en general expresa la idea de la ley como acto normativo supremo e irresistible al que, en línea de principio, no es oponible ningún derecho más fuerte, cualquiera que sea su forma y fundamento ${ }^{14}$ ".

Esta elevação hierárquica da lei e a caracterização do novo paradigma jurídico não deixaram de ser, claro, a expressão da derrota das tradições jurídicas do absolutismo e do ancien régime $e^{15}$, e da conquista pela regulação da violência física. Sobre esta última característica, Nicos Poulantzas refere que:

Esse direito regula também as formas de exercício da repressão física: esse sistema jurídico, essas liberdades "formais" e "abstratas" são também, cumpre destacar, conquistas das massas populares. É nesse sentido, e apenas nesse sentido, que a lei moderna coloca os limites do exercício do poder e da intervenção dos aparelhos de Estado. ${ }^{16}$

Nesta passagem, o filósofo faz alusão a duas importantes características da lei moderna (formalismo e abstração) que foram viabilizadas pela ascensão do paradigma cientificista do direito e que, neste período, elevou-se a custa da marginalização do jusnaturalismo típico do período anterior ${ }^{17}$. Tal paradigma, representado pelo positivismo, promoveu interessantes construções teóricas no sentido de fundamentar, legitimar e desenvolver o Estado de direito, fundado pelas novas Constituições. Assim, à consagração do princípio da legalidade, já mencionado, somaram-se neste contexto a admissão do positivismo legalista, o monopólio do Estado na produção legislativa, a primazia do Poder Legislativo (que acabou confiado à burguesia) e a identificação entre lei e validade jurídica ${ }^{18}$. A consagração desse paradigma jurídico, segundo o professor Julios-Campuzano, foi um dos pilares que sustentaram o Estado liberal de direito, modelo que, em último grau, representou as aspirações da classe burguesa; o outro pilar se encontrava em nível político - tratava-se “da ideologia liberal que, sutilmente manipulada pela nova classe social emergente, perdeu sua marca emancipatória e revolucionária para vincular-se aos interesses econômicos como o liberalismo arraigado e decadente”"19.

\footnotetext{
${ }^{14}$ ZAGREBELSKY, op. cit., p. 24.

15 Ibid., loc. cit.

${ }^{16}$ POULANTZAS, op. cit., p. 90.

17 JULIOS-CAMPUZANO, op. cit., p. 12.

18 Ibid., pp. 10-11.

${ }^{19}$ Ibid., loc. cit.
} 
Negando tanto a concepção marxista tradicional do Estado enquanto puro instrumento ou aparato repressivo quanto a possibilidade da construção de uma "teoria geral do Estado", e aproximando-se do estruturalismo althusseriano, Poulantzas desenvolveu uma complexa teoria do Estado na tentativa de compreender a especificidade deste modelo estatal formado após o declínio do absolutismo e como ele representou os interesses das classes dominantes. Destas observações, algumas categorias formadas são de particular interesse no presente estudo. Assim, o filosofo desenvolve o conceito de estrutura jurídico-política (capitalista, referindo-se ao contexto do direito e Estado modernos), um sistema articulado de quatro conceitos: o "direito capitalista”, o “burocratismo", e seus efeitos, quais sejam o "efeito de isolamento" e o da “representação da unidade"20.

Partindo desse conceito-base, Poulantzas procura compreender o "direito capitalista" e o que ele tem de específico; descobre esta especificidade ao caracterizá-lo como um "sistema axiomatizado, composto de conjunto de normas abstratas, gerais, formais, e estritamente regulamentadas" 21 . Dessa forma, o direito assim caracterizado, ao tratar os indivíduos como sujeitos "livres" e "iguais", contribui para instaurar e sancionar a diferença real - eis que surge seu efeito: o "efeito de isolamento", ou ainda, a “individualização"22. O efeito de isolamento é o ponto de encontro da estrutura jurídico-política com a estrutura econômica que, ao produzir a atomização do coletivo no processo de produção, contribui para a reprodução das relações sociais. Ou seja, o direito moderno constitui uma importante ferramenta de manutenção da nova ordem social instaurada. Corroborando esta ideia, o professor Julios-Campuzano traz uma importante contribuição:

O igualitarismo jurídico expressou-se no reconhecimento puramente formal da igualdade de todos os cidadãos perante a lei; com isso permaneceu comprometido com a preservação de uma ordem social e econômica que se baseava sobre o reconhecimento explícito da desigualdade entre as classes sociais. ${ }^{23}$

O constitucionalismo oitocentista foi caracterizado como um constitucionalismo frágil; por excelência um constitucionalismo de caráter procedimental, que instituía a nova materialidade institucional do Estado, estabelecia competências para a distribuição de poderes e produção legislativa - em suma, um constitucionalismo das “regras do jogo”. A Constituição

${ }^{20}$ SAES, Décio. A questão da autonomia relativa do Estado em Poulantzas. Revista Crítica Marxista, n.7. São Paulo: Xamã, 1998. p. 51.

${ }^{21}$ POULANTZAS, op. cit., p. 84.

22 Ibid., p. 85; SAES, op. cit., p. 49.

23 JULIOS-CAMPUZANO, op. cit., p. 12. 
desta época foi definida como uma norma sui generis de alcance limitado, não superior hierarquicamente a qualquer outra, que ficava a serviço da vontade do legislador; era, assim, “uma norma fundante da ordem jurídica, uma norma básica da ordem política, mas nada mais que isso: uma norma carente, sem maiores pretensões que a de constituir, a de fundar, a ordem política sobre a qual repousa o sistema jurídico"24. Dessa forma, a Constituição se inseriu na estrutura jurídico-política do Estado, cumprindo ainda, segundo Poulantzas, um importante papel para a reprodução das relações produtivas e, portanto, da ordem social: o de comportar as próprias regras de transformação do Estado, "fazendo assim com que suas modificações se tornem transformações reguladas no seio de seu sistema" 25 .

Destarte, as Constituições modernas (em específico das democracias europeias) foram determinantes tanto na derrubada do modelo do Estado absolutista - momento em que Constituição e constitucionalismo se encontram entre as bases do projeto emancipatório moderno -, quanto na construção de um novo modelo de Estado que, afinal, representou o florescimento de um novo paradigma: o positivismo jurídico. Assim, a ascensão do paradigma cientificista do direito constituiu um momento determinante na exposição dessa transformação relativa do lugar ocupado pela Constituição, que passou a contribuir para a manutenção da nova ordem social, assumindo um caráter regulador desta ordem.

De acordo com a abordagem de Boaventura de Sousa Santos, poder-se-ia referir que tal fenômeno tem relação com o abandono da "racionalidade moral-prática" do direito moderno e sua imersão na "racionalidade cognitivo-experimental", típica da ciência moderna, dentro do pilar emancipatório do projeto moderno. Pode-se dizer ainda que esta é uma das expressões do desequilíbrio apresentado neste projeto, que será objeto de análise mais acurada a partir de agora.

\section{CONSTITUIÇÃO E ESTADO COMO PRODUTO DE UM EMBATE TEÓRICO E POLÍTICO}

\subsection{0 desequilíbrio do projeto moderno e a ascensão do ideal emancipatório} (classista) das doutrinas sociais do século XIX

\footnotetext{
${ }^{24}$ Ibid., p. 17.

${ }^{25}$ POULANTZAS, op. cit., p. 89.
} 
O desenrolar do curso histórico promoveu, como corolário do desenvolvimento dessa nova objetividade, marcada pela predominância do modo de produção capitalista nas formações sociais ocidentais, um desequilíbrio entre os princípios que compõem o pilar da regulação de tal forma que, de maneira geral, o princípio do mercado hipertrofiou-se e obteve hegemonia sobre o princípio do Estado, e esses dois juntos, da mesma forma, em detrimento do princípio da comunidade. Tal desequilíbrio se trata na verdade, sob a ótica boaventuriana, de um "processo histórico não linear" que se manifesta de forma diversa nos diferentes períodos do capitalismo, de maneira tal que o princípio do mercado ganha hipertrofia total em um momento inicial, chamado capitalismo liberal. Esta etapa é anterior a uma fase intermediária, denominada capitalismo organizado, correspondente ao período do chamado Estado-Providência, onde os princípios do mercado e do Estado atingem certo equilíbrio "sob pressão do princípio da comunidade". Após, principalmente a partir da década de 1980, percebe-se uma fase de rehegemonização do princípio do mercado sobre os outros dois, na fase chamada capitalismo desorganizado. De acordo com o autor, a teoria política liberal figurou como a expressão mais sofisticada deste desequilíbrio ${ }^{26}$.

Então, o desequilíbrio apresentado pelo projeto moderno foi sustentado pela própria teoria política liberal, que foi o alicerce sobre o qual se deu a emancipação em relação ao Estado absolutista. Esse aparente paradoxo foi um reflexo de alguns dos próprios pressupostos e características dessas teorias - a mais evidente, sem dúvida, é "a total marginalização do princípio da comunidade tal como é definido por Rousseau"27. Essa marginalização decorre do fato de que Rousseau se baseia em uma espécie de contrato social diferenciado daquela que realmente serviu como base para a sociedade liberal - a ideia do contrato social rousseauiano repousa em espécies de obrigações horizontais entre os membros da sociedade, portanto a igualdade formal alcançada pela emancipação burguesa não se torna suficiente; tal é o fundamento de sua crítica sobre a propriedade privada.

Dessa forma, é precisamente na época de maior crescimento e total hipertrofia do princípio do mercado (a do Estado liberal de direito), que surgem o que o sociólogo chama de "as mais brilhantes construções emancipatórias da modernidade" ${ }^{28}$, ou seja, o conjunto das doutrinas sociais do século XIX - que reúne as teorias e movimentos socialistas, anarquistas,

\footnotetext{
${ }^{26}$ SANTOS, op. cit., p. 237.

27 Ibid., p. 239.

28 Ibid., p. 241.
} 
mutualistas, cooperativistas e suas respectivas correntes. Esse conjunto de teorias críticas pretende, de forma geral, apesar de variarem em seus projetos específicos e sobre os métodos a serem empregados, uma nova revolução social baseada em um projeto de sociedade que supere o predomínio do modo de produção capitalista e expressa, em última análise, uma nova forma de emancipação. Toda a conjuntura que acompanha esse período do capitalismo (e do Estado) liberal - cite-se as condições de existência das classes trabalhadoras - foi a base que sustentou a crítica social e o surgimento dessas novas correntes teóricas e políticas emancipatórias; entretanto, o marxismo foi sem dúvida seu principal expoente.

Não cabe aqui empreender um vasto estudo sobre os fundamentos de crítica de cada uma das teorias levantadas, pois já são bem conhecidos e vai além do pretendido pelo trabalho; o que interessa no momento é trazer à baila a espécie de liberdade que de que se fala neste contexto teórico-político e identificar o tipo de emancipação pretendida, para então constatar algumas de suas consequências. Assim, quando se tem em mente a emancipação proposta pelas doutrinas sociais oitocentistas, fala-se de uma liberdade e emancipação em sentido material, baseadas na ideia de liberdade positiva. Sobre isso, Norberto Bobbio é enfático ao afirmar que “um dos traços comuns a todos esses escritores [da tradição que o autor denomina 'libertária'] é certamente a maior valorização da liberdade positiva com relação à liberdade negativa, ou até mesmo a exclusiva consideração da primeira em detrimento da segunda"29.

Dessa forma, o mestre de Turim define a liberdade positiva:

Por liberdade positiva, entende-se - na linguagem política - a situação na qual um sujeito tem a possibilidade de orientar seu próprio querer no sentido de uma finalidade, de tomar decisões, sem ser determinado querer de outros. [...] é positiva porque indica, ao contrário, a presença de algo, ou seja, de um atributo específico de meu querer, que é precisamente a capacidade de se mover para uma finalidade sem ser movido. ${ }^{30}$

A crítica marxiana sobre o processo revolucionário empreendido anteriormente tem a particularidade de demonstrar o fato de que este processo possibilitou tão-somente a emancipação política do homem. Assim, à transição entre os períodos pré-moderno e moderno, acompanhada dessa conquista dos direitos civis e políticos, somou-se uma nova concepção de

${ }^{29}$ BOBBIO, op. cit., p. 73.
30 lbid., p. 51. 
cidadania - a cidadania civil e política. Mencionando Thomas Humphray Marshall ${ }^{31}$, Santos explica o teor do conceito de cidadania:

Segundo Marshall, na linha da tradição liberal, a cidadania é o conteúdo da pertença igualitária a uma dada comunidade política e afere-se pelos direitos e deveres que o constituem e pelas instituições a que dá azo para ser social e politicamente eficaz. A cidadania não é, por isso, monolítica; é constituída por diferentes tipos de direitos e instituições; é produto de histórias sociais diferenciadas protagonizadas por grupos sociais diferentes. ${ }^{32}$

Entretanto, segundo as doutrinas sociais emergentes, caberia ir além: uma emancipação mais profunda, que viabilizasse a libertação do homem do poder econômico e ideológico excessivo propiciado pelo acúmulo do capital a partir do processo de alienação do trabalho - a construção de uma sociedade onde, no dizer clássico, o livre desenvolvimento de cada um seja a condição para o livre desenvolvimento de todos.

Um dos pontos-chave para o entendimento dos acontecimentos posteriores reside na própria estrutura teórica dessas doutrinas - trata-se da construção de um "sujeito monumental" (a classe operária, enquanto classe oprimida) capaz de se contrapor a outro "sujeito monumental" construído para a manutenção da estrutura social formada (o Estado). Dessa forma, inicialmente Marx cogitou que o desenvolvimento do capitalismo inevitavelmente conduziria a uma proletarização homogeneizante da população e que esta, tomada de sua consciência enquanto classe, conduziria à nova revolução pretendida - em suma, a emancipação aspirada teria uma forte tendência e base classista. Porém, como bem anotou Santos, "sabemos hoje que o capitalismo não proletarizou as populações nos termos previstos por Marx e que, em vez de homogeneizar globalmente os trabalhadores, se alimentou das diferenças existentes ou, quando as destruiu, criou outras em seu lugar" ${ }^{33}$. Como será analisado a partir de agora, a organização dos trabalhadores e as lutas populares que se seguiram foram, entretanto, de extrema importância para a perturbação daquele sistema estatal pretensamente coerente e unívoco.

\footnotetext{
${ }^{31}$ Muitas críticas surgiram em relação ao trato teórico marshalliano e sua concepção evolucionista de cidadania e dos direitos, de forma a subestimar ou desconsiderar o papel das lutas políticas e das tensões próprias desta instância nesses processos. Como exemplo da exposição e desenvolvimento desta polêmica, cite-se o trabalho de Décio Saes (2003), publicado em Crítica Marxista. Entretanto, Santos refere que a análise de Marshall possui como mérito a "articulação que opera entre cidadania e classe social e nas consequências que dela retira para caracterizar as relações tensionais entre cidadania e capitalismo" (op. cit., p. 244).
}

${ }^{32}$ SANTOS, op. cit., pp. 243-244.

33 Ibid., p. 242. 


\subsection{Estado (e Constituição) como uma condensação material de relações de força}

Os postulados teóricos das doutrinas sociais do século XIX foram determinantes na construção das linhas de ação política dos movimentos sociais e partidos operários e na organização política dos trabalhadores, principalmente a partir da segunda metade do século. As agitações políticas dessa época não foram capazes de modificar as estruturas das formações sociais concretas nas democracias ocidentais tal como fora previsto por seus teóricos e defensores; provocaram, entretanto, relevantes transformações nas mesmas. As lutas políticas deflagradas na transição entre os séculos XIX e XX foram determinantes na conquista, pelas classes dominadas, de um novo rol de direitos que acabaram sendo também inscritos nas Constituições. Essas conquistas traduziam o surgimento do Estado Social de Direito, que se contrapunha ao modelo liberal anterior e implicava a prestação de serviços básicos por parte do Estado à população - segundo a abordagem de Santos, esse novo modelo estatal correspondeu, à economia, ao período do capitalismo organizado.

A pressão dos movimentos trabalhistas no seio da sociedade civil organizada (leia-se: do princípio da comunidade) foi, de acordo com o professor Julios-Campuzano, citando o jurista espanhol Antonio Enrique Pérez-Luño, determinante na denúncia de que o catálogo de direitos fundamentais não se constitui em uma obra fechada e acabada, e que o constitucionalismo precisava atender às necessidades de garantias para além da igualdade formal liberal. Nas palavras de Julios-Campuzano:

os proclamas puramente formais do constitucionalismo liberal [...] necessitavam do acréscimo dos direitos-prestação que permitiam a conquista efetiva de maiores doses de igualdade material e que se traduziam em um compromisso ativo do Estado na transformação da ordem social e na remoção de obstáculos que impediam o exercício efetivo das liberdades. ${ }^{34}$

Dessa forma, as constituições das formações estatais sob o modelo social, que se desenvolveu no início do século XX e se generalizou após o fim da Segunda Guerra Mundial, foram fortemente influenciadas pelo desenvolvimento dos direitos sociais. 0 rol de direitos fundamentais inscritos nas cartas constitucionais foi estendido para atender às prestações do Estado Social; tais documentos, então, além de estabelecer competências e garantir as

\footnotetext{
${ }^{34}$ JULIOS-CAMPUZANO, op. cit., p. 21.
} 
liberdades individuais, passaram a também a regular determinado nível de intervenção estatal na estrutura econômica, na tentativa de construir meios de garantia dos novos direitos.

Mantendo constante diálogo com a teoria relacional do poder de Michel Foucault, mas sem se desligar do paradigma marxista presente ao longo de sua produção teórica, Nicos Poulantzas desenvolve, em sua última obra de prestígio internacional, uma forma de interpretar o Estado que muito auxilia na compreensão desses acontecimentos. Procurando compreender as transformações pelas quais passa o Estado nas diferentes fases do capitalismo bem como suas variações no seio de cada uma destas, o autor desenvolve a noção de Estado enquanto uma condensação material de uma relação de forças. Dessa forma, o Estado é identificado com as classes não por uma relação de exterioridade, típica das concepções instrumentalistas de Estado-coisa ou Estado-sujeito, mas por uma relação intrínseca das lutas (de classe ou não), que se interiorizam no Estado (e inclusive o ultrapassam) - em suma, o Estado reflete a correlação de forças entre as classes em uma dada sociedade e em um período específico.

O Estado, então, não pode ser entendido como uma entidade monolítica, mas sim como esta condensação repleta de fissuras e permeada de contradições, que são traduzidas pelas contradições de classe. Ainda, trata-se de uma condensação material porque possui uma ossatura material própria, que se reflete em uma autonomia relativa em relação ao conjunto de classes dominantes (bloco no poder) ou frações de classe dominante, e as classes dominadas; nas palavras do autor:

O Estado não se reduz à relação de forças, ele apresenta uma opacidade e uma resistência próprias. Uma mudança na relação de forças entre as classes certamente tem sempre efeitos no Estado, mas não se expressa de maneira direta e imediata: ela esgota a materialidade de seus diversos aparelhos e só se cristaliza no Estado sob sua forma refratada e diferencial segundo seus aparelhos. ${ }^{35}$

Considerado dessa maneira, o Estado possui, frente às classes dominantes o papel de organização e representação; constitui a unidade política das classes dominantes, instaura-as como dominantes. Mas o Estado não concentra tão-somente a relação de forças entre as frações de classe do bloco no poder, "mas também a relação de forças entre estas e as classes dominadas" ${ }^{36}$ e, dessa forma, se dá a inserção das lutas populares no aparelho de Estado:

$\mathrm{Na}$ realidade, as lutas populares atravessam o Estado de lado a lado, e isso não acontece porque uma entidade intrínseca penetra-o do exterior. Se as lutas

\footnotetext{
${ }^{35}$ POULANTZAS, op. cit., p. 132-133.

${ }^{36}$ Ibid., p. 143.
} 
políticas que ocorrem no Estado atravessam seus aparelhos, é porque essas lutas estão desde já inscritas na trama do Estado do qual elas esboçam uma configuração estratégica. ${ }^{37}$

Um dos resultados da interioridade dessas lutas ao Estado é formação de compromissos em relação às classes dominadas, na forma de perturbações e modificações pontuais em suas estruturas e que, em último grau, representam conquistas daquelas. Dessa forma o rol de direitos sociais inscritos nas Constituições do Estado social constituiu verdadeira conquista de compromissos das classes dominadas frente às classes detentoras do poder de Estado.

Utilizando-se a fórmula de Peter Häberle, que relaciona a compreensão do Estado à Constituição - "tal constituição, tal Estado" ou "tanto Estado quanta a Constituição" -, aplicada pelo professor português José Joaquim Gomes Canotilho ${ }^{38}$, poder-se-ia considerar então a Constituição como um fruto dessa condensação material de relação de forças, que reproduz em seu seio as contradições e fissuras inerentes a essa condição do Estado. Em outras palavras, a Constituição (e, consequentemente, o constitucionalismo) revela $(\mathrm{m})$ ser, nesta época, um processo não-monolítico, mas tenso em si; isto implica dizer que os princípios de homogeneidade e coerência interna do ordenamento jurídico pretendidos pela doutrina política liberal foram postos em xeque pelo curso histórico - aos poucos tornava-se evidente a necessidade de novas concepções jurídicas que auxiliassem na compreensão deste processo.

\section{O NEOCONSTITUCIONALISMO: PRÁXIS EMANCIPATÓRIA?}

\subsection{Ascensão e crise da cidadania social, novos movimentos sociais, globalização e pluralismo}

As lutas populares empreendidas durante os últimos dois séculos, inspiradas nas doutrinas sociais do século XIX, se não promoveram a desestruturação das bases de produção das formações sociais concretas ocidentais, como fora pretendido por seus teóricos, geraram, como foi visto, inegáveis consequências às mesmas. Tais consequências traduzem-se na conquista dos direitos sociais pelas classes trabalhadoras, inaugurando um novo contexto social, marcado pelo paradigma do Estado Social de Direito ou Estado-Providência.

\footnotetext{
${ }^{37}$ Ibid., loc cit.

${ }^{38}$ CANOTILHO, Joaquim J. G. O Estado adjetivado e Teoria da Constituição. Revista da ProcuradoriaGeral do Estado, Porto Alegre, v. 25, n 56, dez 2002. p. 27.
} 
Esse novo período relaciona-se com a segunda fase do capitalismo tal como periodizado por Boaventura de Sousa Santos, denominado capitalismo organizado. Assim, esse conjunto formado pelo Estado Social (no âmbito superestrutural), pelo capitalismo organizado (como nova configuração econômica), e pela ascensão dos direitos sociais (na teoria e prática jurídica), possui íntima relação com a inauguração de uma nova categoria pela qual o homem é inserido socialmente - trata-se da chamada cidadania social. Assim, sobre a cidadania e os direitos sociais, ainda sentencia o politólogo português:

O segundo período do capitalismo nos países centrais, o capitalismo organizado,
caracteriza-se pela passagem da cidadania cívica e política para o que foi
designado por "cidadania social", isto é, a conquista de significativos direitos
sociais [...] Os direitos sociais só se desenvolvem no nosso século e, com
plenitude, depois da Segunda Guerra Mundial; têm como referência social as
classes trabalhadoras e são aplicados através de múltiplas instituições que, no
conjunto, constituem o Estado-Providência. ${ }^{39}$

Todavia, o impacto da ascensão da cidadania social fez com que o homem perdesse grande parte de seu potencial emancipatório, impulsionado pela inserção quase total dos trabalhadores e a população em geral na rotina de produção (e sua reprodução), e agravado pela redução do campo político e pela crise da representação democrática ${ }^{40}$. Como reação a essa negatividade, que representa em último grau a sobreposição da cidadania à subjetividade humana, os anos 60 do século passado foram o marco que caracterizou o princípio da revolta contra essa objetividade atomizante. Os novos movimentos surgidos naquela época trouxeram o protagonismo do movimento estudantil, que se baseou numa perspectiva transclassista, identificando “múltiplas opressões, tanto ao nível da produção (trabalho alienado), como da reprodução social (família burguesa, autoritarismo da educação, monotonia do lazer, dependência burocrática)" ${ }^{41}$.

As movimentações sociais ocorridas a partir desse período carregam consigo o cerne do que Santos chama de novos movimentos sociais (NMSs). Tais movimentos possuem particularidades que se manifestam de forma mais ou menos intensa, dependendo do ambiente no qual se desenvolvem, mas, de forma geral, com o isolamento político da classe operária, levam a marca dessa postura de especificidade das lutas, baseadas na identificação de opressões

\footnotetext{
39 SANTOS, op. cit., pp. 243-244.

40 lbid., p. 249.

41 Ibid., loc cit.
} 
para além da perspectiva classista de outrora. São exemplos desses novos sujeitos sociais determinados movimentos feministas, étnicos, pacifistas, ecológicos, etc.

No debate suscitado pelo surgimento dos NMSs, não faltaram críticas sobre a efetiva novidade desses movimentos ou sobre suas consequências ${ }^{42}$. Cabe, entretanto, salientar algumas das características, levantadas pelo autor lusitano, desses novos atores sociais, que também constroem a base do que se chama hoje de sociedades pluralistas ${ }^{43}$. Assim, Boaventura de Sousa Santos é enfático ao asseverar a efetiva novidade ideológica e organizativa desses movimentos, apesar de não se poder tomá-la em sentido absoluto ${ }^{44}$ - e, completando, refere que "a novidade dos NMSs não reside na recusa da política, mas, ao contrário, no alargamento da política para além do marco liberal da distinção entre Estado e sociedade civil" ${ }^{45}$. Sobre as lutas empreendidas pelos NMSs, afirma ainda o autor que: "através dela [da novidade nas estruturas de ação e organização dos NMSs] continuam e aprofundam a luta pela cidadania, não sendo correcto justificar com ela um pretenso desinteresse pelas questões da cidadania" ${ }^{46}$.

Tendo em vista o contexto histórico atual, resta muito recente a inserção dos novos movimentos sociais no campo político, não sendo possível ainda empreender um balanço seguro sobre seus os exatos resultados em termos emancipatórios. Não se pode, entretanto, afastar de pronto as possíveis contribuições desses movimentos já identificadas no âmbito do político. Dessa forma, cabe lembrar que

os NMSs são sinal de transformações globais no contexto político, social e cultural da nossa contemporaneidade e, por isso, os seus objectivos serão parte permanente da agenda política dos próximos anos, independentemente do sucesso, necessariamente diverso, dos diferentes movimentos concretos. ${ }^{47}$

\footnotetext{
${ }^{42}$ Tal debate fica evidenciado em: SANTOS, op. cit., p. 261 e ss.

${ }^{43}$ Apesar de não se concordar por completo com os fundamentos desta denominação, é o termo utilizado por Gustavo Zagrebelsky em várias passagens de sua obra para caracterizar as sociedades atuais marcadas pela pluralidade de grupos sociais com interesses, ideologias e projetos diferentes.

${ }^{44}$ Sobre isso, o autor defende que não se pode compreender os novos movimentos sociais a partir de uma teoria unitária. Ademais, cita a peculiar "impureza" dos NMSs na América Latina, que podem p. ex., apresentar uma combinação de movimento de orientação classista "acompanhado de juízos étnicos e sexuais, que o diferenciam e o assimilam a outros movimentos de orientação culturalista com conteúdos classistas". Termina por afirmar que "reside nesta 'impureza' a verdadeira novidade nos NMSs na América Latina, e o seu alastramento aos NMSs dos países centrais é uma das condições da revitalização da energia emancipatória destes movimentos em geral." (Ibid., p. 263)
}

${ }^{45}$ Ibid., p. 263.

${ }^{46}$ Ibid., p. 264.

${ }^{47}$ Ibid., p. 265. 
Esta nova caracterização dos movimentos emancipatórios na base da sociedade civil organizada coincidiu, principalmente a partir da década de 1980, com a implantação do modelo neoliberal, que fora desenvolvido entre início e meados do século ${ }^{48}$, e outros fenômenos relacionados, tais como a globalização nestes moldes e o consequente enfraquecimento do poder estatal frente à difusão de centros de poder alternativos. Tal modelo reivindicava, entre outros pontos, a radical superação do modelo de Estado Social, promovendo-se o desmonte da estrutura prestacional do Estado e a sua desresponsabilização na promoção da igualdade material. Em suma, este contexto foi acompanhado pelo surgimento do que Sousa Santos denominou capitalismo desorganizado; da reascensão do "princípio do mercado" sobre os demais; da produção de "soluções capitalistas novas para responder eficazmente aos desafios dos anos 60"49.

0 projeto neoliberal, entretanto, não foi plenamente aplicado nas experiências concretas em que se fez presente, sempre houve focos de resistência mais ou menos eficazes que the impediram o integral desenvolvimento. Tais resistências também evidenciam, diga-se de passagem, a tese de Poulantzas sobre a internalização das lutas no aparelho de Estado e sua ossatura material própria, que refrata os efeitos das lutas antes de serem nele assimiladas.

Dessa forma, o contexto formado pela especificação total ou relativa das lutas emancipatórias na base da sociedade civil, pelo enfraquecimento relativo (já que ainda mantém relevante presença nas formações sociais concretas) do modelo de Estado Social, pelo enfraquecimento do Estado como centro de poder, pela globalização econômica e pela já demonstrada insuficiência da ideia de um ordenamento jurídico monolítico, unívoco e coeso em si também formam, como já fora mencionado, as bases do que se chamou de sociedades pluralistas. É no seio destas sociedades que se manifesta um novo fenômeno que propõe resgatar o sentido do ordenamento jurídico; trata-se na verdade de uma série de posturas teóricas no âmbito da Ciência Jurídica que, em conjunto, tem sido denominado neoconstitucionalismo ${ }^{50}$. Tal fenômeno será objeto de análise mais acurada nos tópicos seguintes.

\footnotetext{
${ }^{48}$ Principalmente com as construções de teóricos das chamadas Escola Austríaca e de Chicago, como Ludwig Von Misses, Friedrich Von Hayek, e Milton Friedman.

${ }^{49}$ Ibid., p. 251.

${ }^{50}$ Sobre as formas de denominar este novo paradigma, Valéria Ribas do Nascimento ainda destaca: "são muitas as variações terminológicas que costumam ser encontradas para o referido fenômeno, tais como constitucionalismo do Pós-Guerra, pós-positivismo, neoconstitucionalismo, ou constitucionalismo contemporâneo, sendo que todas remetem a diferentes relações entre os poderes estatais e ao grau de importância dos valores existentes nos ordenamentos jurídicos." (NASCIMENTO, Valéria Ribas do. 0 tempo
} 


\subsection{Estado constitucional e neoconstitucionalismo: notas gerais}

De acordo com Miguel Carbonell, o constitucionalismo contemporâneo pode ser definido como um conceito que procura explicar um conjunto de fenômenos relativamente recentes dentro do chamado Estado constitucional, que se consolidou a partir do final da Segunda Guerra Mundial (sobretudo após a década de 1970), marcados principalmente pelo surgimento de Constituições com altos níveis de normas materiais ou substantivas, que condicionam a atuação do Estado por meio da ordenação de certos fins e objetivos ${ }^{51}$. Na verdade, explica Carbonell, pode-se ter o constitucionalismo contemporâneo (ou, como prefere o autor, o neoconstitucionalismo) como um fenômeno verdadeiramente novo se se considerá-lo como um conjunto que deve ser analisado sob três níveis distintos ${ }^{52}$, quais sejam: (a) os novos textos Constitucionais já mencionados; (b) as práticas jurisprudenciais, que surgem também em grande medida como consequência deste modelo constitucional; e (c) de novos desenvolvimentos teóricos, que partem dos outros dois níveis citados e que contribuem não tão-somente para explicar estes fenômenos jurídicos, como também criá-los ${ }^{53}$.

Nas palavras de André Rufino do Vale, o neoconstitucionalismo se trata de

um conjunto de posturas teóricas que adquiriram sentidos comuns ao tentar explicar o direito dos Estados constitucionais, especificamente aqueles que [...] adotaram constituições caracterizadas pela forte presença de direitos, princípios e valores e de mecanismos rígidos de fiscalização da constitucionalidade [...] como as Constituições da Itália (1948), Alemanha (1949) e Espanha (1978), contexto no qual as Constituições de Portugal (1976) e do Brasil (1988) inseremse perfeitamente. ${ }^{54}$

Entretanto, lembra o autor que os teóricos neoconstitucionalistas não podem ser reunidos em uma mesma corrente de pensamento, mas que “em suas teorias é possível encontrar uma série de coincidências e tendências comuns que podem conformar uma 'nova cultura jurídica', um 'paradigma constitucionalista in statu nascendi', ou, em outros termos, 'o

das reconfigurações do constitucionalismo: os desafios para uma cultura cosmopolita. São Paulo: LTr, 2011. p. 83)

51 CARBONELL, Miguel. Nuevos Tiempos para el Constitucionalismo (Prólogo). In: (ed.). Neoconstitucionalismo(s). Madrid: Editorial Trotta, 2005. pp. 9-10.

${ }^{52} \mathrm{Tal}$ análise deve ser feita em conjunto por que, se tomados isoladamente, tais elementos não constituem necessariamente inovações que justifiquem uma nova identificação (Ibid., pp. 11-12).

${ }^{53}$ Ibid., pp. 9-11.

${ }^{54}$ VALE, André R. do. Aspectos do neoconstitucionalismo. Revista Brasileira de Direito Constitucional (RBDC), n 9. São Paulo: ESDC, 2007. p. 68. 
paradigma do Estado constitucional de direito" "55. Dessa forma, apesar do ecletismo teórico presente nas obras do constitucionalismo contemporâneo, percebem-se linhas gerais que contribuem na caracterização do fenômeno, como: (a) a constitucionalização dos princípios e sua elevação à categoria de norma; (b) o consequente desenvolvimento da ponderação como método de interpretação e aplicação adequado ao saneamento de conflitos entre os bens jurídicos tutelados por esta carga principiológica; (c) a concepção da Constituição como norma, que irradia efeitos por todo o ordenamento jurídico, condicionando a totalidade da atividade jurídica; (d) o protagonismo judicial, quando comparado com o modelo constitucional oitocentista, que privilegiava a atuação do legislador; e (e) a retomada das reflexões acerca da relação entre o Direito e a moral ${ }^{56}$.

Dessa maneira, o neoconstitucionalismo parte basicamente ao trato teórico relacionado a um novo modelo de Constituição, na tentativa não só de descrever a constitucionalização dos Estados contemporâneos, mas também de contribuir com a própria criação do Direito Constitucional $^{57}$. Esse modelo constitucional é descrito por André Rufino do Vale como "modelo axiológico de Constituição como norma"; uma forma de Constituição carregada axiologicamente que promove, através do incremento no rol de direitos fundamentais, a positivação de valores, capazes de condicionar a atividade jurídica do Estado. A este novo modelo constitucional corresponde então um tipo de Estado que, para diferenciar-se do Estado de direito nas suas versões tradicionais, tem sido chamado (por autores como Luigi Ferrajoli, Gustavo Zagrebelsky e Luis Prieto Sanchís) Estado constitucional, apesar das ambiguidades que o termo carrega. Sobre este modelo estatal, o constitucionalista refere que sua marca distintiva "é a constitucionalização do ordenamento jurídico através das normas de direitos fundamentais, que traduzem para a linguagem normativa as opções éticas e políticas da sociedade" ${ }^{58}$.

Algumas reflexões, entretanto, têm evidenciado alguns resíduos teóricos contidos em determinadas formulações do constitucionalismo contemporâneo, que remetem às bases que sustentaram o constitucionalismo moderno. Exemplo disso pode ser encontrado em recente trabalho de Moysés Pinto Neto ${ }^{59}$, onde o autor explicita a forte influência da teoria política liberal - e do modelo de contratualismo que esta corrente implica - em determinados

\footnotetext{
${ }^{55}$ Ibid., p. 67. Nesse sentido, também: NASCIMENTO, op. cit., p. 86.

${ }^{56}$ Ibid., pp. 67-68

${ }^{57}$ NASCIMENTO, op. cit., p. 84.

${ }^{58}$ Ibid., p. 69.

${ }^{59}$ PINTO NETO, Moysés. A Matriz Oculta do Direito Moderno: crítica do constitucionalismo contemporâneo. Cadernos de Ética e Filosofia Política. n 17, São Paulo, 2010.
} 
desenvolvimentos de autores neoconstitucionalistas (principalmente da teoria garantista de Luigi Ferrajoli). Baseando-se na teoria do estado de exceção como regra de Walter Benjamin e outros autores, como Giorgio Agambem, Pinto Neto defende então que a manutenção destas concepções é insuficiente para a explicação de como os sujeitos que estariam à parte do suposto contrato são justamente os que sentem mais profundamente a ação estatal.

Para além desta discussão, cabe, como proposto, apontar algumas considerações sobre a relação entre o constitucionalismo contemporâneo e as lutas políticas emancipatórias desenvolvidas no seio das sociedades contemporâneas. Assim, tentar-se-á empreender uma aproximação entre algumas proposições teóricas do constitucionalismo contemporâneo partindo da tese do direito dúctil, formulada por Gustavo Zagrebelsky - e as categorias já trabalhadas no âmbito da teoria poulantziana do Estado ${ }^{60}$. Adverte-se, entretanto, que as considerações feitas a partir de então não têm a pretensão de esgotarem-se, em um estudo exaustivo; do contrário, esta aproximação pretende explicitar apontamentos preliminares que possam instigar e contribuir para desenvolvimentos posteriores.

\subsection{O direito dúctil: sobre a "ductilização" da estrutura jurídico-política do Estado e a abertura às lutas políticas}

$\mathrm{Na}$ obra El derecho dúctil; Ley, derecho, justicia, o constitucionalista Gustavo Zagrebelsky sustenta a tese de que o direito passou por uma profunda transformação a partir das alterações sucedidas no seio das Constituições e o consequente surgimento do atual modelo de Estado que essa configuração comporta - o Estado constitucional ${ }^{61}$. Para o autor italiano, a

\footnotetext{
${ }^{60}$ Esse diálogo com a obra do autor grego é justificado também pela negligência com que esta tem sido tratada em sua relação com o direito, o que é bem verificado por Luiz Eduardo Motta: "Paradoxalmente, essa contribuição ainda não foi totalmente recuperada no presente contexto, em que o direito voltou a ocupar um lugar de destaque nas ciências sociais a partir do fenômeno da judicialização da política e das relações sociais. [...] Entender o papel dos operadores jurídicos no campo político e de suas intervenções sejam as de caráter conservador ou progressista -, como também analisar o papel que desempenham dentro do Estado capitalista ao abarcarem as demandas de caráter popular ou defenderem os representantes do grande capital, são motivos mais do que suficientes para perceber que a teoria poulantziana está na ordem do dia e que é necessário retomar e desenvolver uma teoria do direito e do Estado a partir de seus pressupostos, que representam uma alternativa ao paradigma liberal que ainda predomina no campo do direito como também da ciência política." (MOTTA, Luiz Eduardo. Poulantzas e o Direito. DADOS - Revista de Ciências Sociais, Rio de Janeiro, Vol. 53, n² 2, 2010, p. 396)

${ }^{61}$ Sobre a denominação utilizada, o autor lembra que não raro a forma de Estado atual é vista como uma versão particular do Estado de direito. Esta visão não é, segundo Zagrebelsky, necessariamente equivocada, entretanto, não se deve com isso acreditar em uma continuidade histórica capaz de encobrir
} 
imagem capaz de transportar a ideia exata desse novo desenho jurídico é a da ductilidade; as atuais constituições, dotadas de ductilidade constitucional, seriam a base do que Zagrebelsky denomina direito dúctil ${ }^{62}$.

A ductilidade constitucional implica na constitucionalização de diversos princípios que integram a vida política das sociedades atuais e que são capazes de fornecer legitimidade para cada um dos atores sociais imprimirem ao Estado uma ou outra orientação. Por isso, tais princípios, que podem inclusive serem contraditórios entre si, não devem ser assumidos em caráter absoluto. Daí a ideia de maleabilidade e a abstração criada pelo jurista quando refere que "el derecho constitucional es un conjunto de materiales de construcción, pero el edificio concreto no es obra de la Constitución en cuanto tal, sino de una política constitucional que versa sobre las posibles combinaciones de esos materiales" ${ }^{\prime 63}$. As constituições das sociedades pluralistas atuais, conclui, não carregam um projeto predeterminado de vida em comum, mas suas condições de possibilidade; nas palavras do autor:

La asunción del pluralismo en una Constitución democrática es simplemente una propuesta de soluciones y coexistencias posibles, es decir, un "compromiso de las posibilidades" y no un proyecto rígidamente ordenador que pueda asumirse como un a priori de la política con fuerza propia, de arriba hacia abajo. Sólo así prodremos tener constituciones 'abiertas', constituciones que permitan, dentro de los límites constitucionales, tanto la espontaneidad de la vida social como la competición para asumir la dirección política, condiciones ambas para la supervivencia de una sociedad pluralista y democrática. ${ }^{64}$

Eis, dessa forma, os termos que devem conduzir o direito constitucional atual: coexistência (de princípios e valores) e compromisso (com as possibilidades) ${ }^{65}$.

A ideia de ductilidade do direito é construída com base em uma desestruturação dos alicerces fundamentais do modelo jurídico positivista, impulsionada por uma série de fatores que, quando tomados em conjunto ${ }^{66}$, são capazes de traduzir esta nova conjuntura. Destarte, a imagem de um direito maleável, flexível, contra a rigidez do paradigma jurídico cientificista de

as diferenças entre o atual Estado constitucional e o Estado de direito em suas versões tradicionais (op. cit., p. 22).

62 Ibid., p. 14.

${ }^{63}$ Ibid., p. 13.

${ }^{64}$ Ibid., p. 14

${ }^{65}$ Ibid., p. 15.

${ }^{66} \mathrm{Tal}$ como Miguel Carbonell acentuou em sua obra (ver: nota de rodapé $\mathrm{n}^{\circ} 52$ ), refere o autor que "no se pretende decir nada nuevo, pues todos estos elementos son bien conocidos. Pero es el conjunto que lo destaca." (ZAGREBELSKY, op. cit., p. 9) 
outrora, se insere em uma perspectiva pós-positivista ${ }^{67}$. É a partir de alguns elementos dessa deformação do positivismo, verificados por Zagrebelsky, que se indica uma transformação da estrutura jurídico-política do Estado.

Como fora afirmado, a estrutura jurídico-política é formada por quatro conceitos que se articulam entre si, entre eles o chamado "direito capitalista”. Poulantzas afirmara que tal conceito era caracterizado como aquele "sistema axiomatizado, composto de conjunto de normas abstratas, gerais, formais, e estritamente regulamentadas". Uma caracterização como esta expõe de forma simplificada a estrutura normativa do paradigma positivista então dominante, mas que, à época ${ }^{68}$, já apresentava sinais de decadência. Segundo Zagrebelsky, o surgimento do direito dúctil tem relação direta com a desestruturação deste paradigma, de maneira tal que as características de generalidade e abstração da lei como norma jurídica foram deterioradas, relativizadas. Refere o autor que:

La época actual viene marcada por la "pulverización" del derecho legislativo, ocasionada por la multiplicación de leyes de carácter sectorial y temporal, es decir "de reducida generalidad o de bajo grado de abstracción", hasta el extremo de las leyes-medida y las meramente retroactivas, en las que no existe una intención "regulativa" en sentido propio: en lugar de normas, medidas. ${ }^{69}$

Em seguida, afirma o papel do pluralismo social neste processo, que seria o responsável pela dupla crise dos princípios de generalidade e abstração:

\footnotetext{
Sintéticamente, las razones de la actual desaparición de las características "clásicas" de la ley pueden buscarse sobre todo en los caracteres de nuestra sociedad, condicionada por una amplia diversificación de grupos y estratos sociales que participan en el "mercado de las leyes". ${ }^{70}$
}

Pode-se afirmar, portanto, que houve uma transformação no seio de um dos conceitos nucleares da estrutura jurídico-política do Estado - o direito capitalista -, tal como construída teoricamente por Poulantzas. Aliás, o próprio autor, em sua obra final, ao analisar o fenômeno que denominou estatismo autoritário, já percebera e esboçara, embora com fundamentos parcialmente diferentes, sinais desse enfraquecimento do "império da lei"; o que chamou de "recuada da lei"71 72 . Assim, tendo em vista que as estruturas são tidas como "conjuntos de

\footnotetext{
${ }^{67}$ VALE, op. cit., pp. 72-73.

${ }^{68} \mathrm{O}$ texto de L'etat, le pouvoir, le socialisme, de Poulantzas, foi publicado originalmente em 1978.

${ }^{69}$ ZAGREBELSKY, op. cit., p. 37.

${ }^{70}$ Ibid., loc. cit.

71 POULANTZAS, op. cit., pp. 223 e ss.; JESSOP, Bob. O Estado, o poder o socialismo de Poulantzas como um clássico moderno. Rev. Sociol. Polít., Curitiba, v. 17, n. 33, jun. 2009. p. 139.
} 
valores que regulam e enquadram de modo durável as práticas sociais de um certo tipo"73, essa transformação, a flexibilização do direito, sua ductilização, reflete na estrutura a qual esse conjunto de valores pertence: ter-se-ia, portanto, uma ductilização da própria estrutura jurídico-política.

Um dos resultados expressos de forma clara por Zagrebelsky a partir desta deformação do paradigma positivista é a quebra da homogeneidade do ordenamento jurídico, resultante da maior inserção dos atores sociais (e da correlação de forças que daí surge) na trama do Estado, responsável por uma produção jurídica heteróclita. Nas palavras do jurista italiano:

\begin{abstract}
Cada uno de los actores sociales, cuando cree haber alcanzado fuerza suficiente para orientar en su propio favor los términos del acuerdo, busca la aprobación de nuevas leyes que sancionen a la nueva relación de fuerzas. Y esta ocasionalidad es la perfecta contradicción de la generalidad y abstracción de las leyes, ligadas a una cierta visión racional del derecho impermeable al puro juego de las relaciones de fuerzas.

[...]

A la pulverización de la ley se añade la heterogeneidad de sus contenidos. El pluralismo de las fuerzas políticas y sociales en liza, admitidas todas a la competición para que puedan afirmar sus pretensiones en las estructuras del Estado democrático y pluralista, conduce a la heterogeneidad de los valores e intereses en las leyes. ${ }^{74}$
\end{abstract}

Nesse sentido, a própria estrutura do ordenamento jurídico representa uma maior abertura às relações de força presentes no seio das sociedades; aquela condensação material de relações de força, tal como Poulantzas definira do Estado em sua última fase teórica ${ }^{75}$, torna-se mais evidente quando se visualiza o momento jurídico atual. Sobre isso, Zagrebelsky é preciso:

La ley - en este punto de su historia - ya no es la expresión 'pacífica' de una sociedad política internamente coherente, sino que es manifestación e instrumento de competición y enfrentamiento social; no es el final, sino la

\footnotetext{
72 Como referiu Bob Jessop (op. cit., p. 131), Poulantzas fora altamente presciente ao analisar estas transformações no direito e a consequente configuração do estatismo autoritário. Anote-se que percebera esses fenômenos ainda no final da década de 1970, mais de quinze anos antes da primeira publicação de $E l$ derecho dúctil de Gustavo Zagrebelsky.

${ }^{73}$ SAES, op. cit., p. 48.

${ }_{75}^{74}$ ZAGREBELSKY, op. cit., p. 37.

${ }^{75}$ Ao longo de seu desenvolvimento teórico, Poulantzas passou por no mínimo três diferentes fases, que refletem o momento de profunda efervescência intelectual vivida na França das décadas de 60 e 70. Sempre ligado ao marxismo, teve uma fase inicial de inspiração existencialista, com forte influência de Jean-Paul Sartre; após, aproximou-se profundamente do estruturalismo de Louis Althusser. A última fase referida é onde o autor busca novas fontes para relacionar com seus apontamentos anteriores - estabelece com Foucault, por exemplo, constante diálogo, apesar de se visualizar neste caso uma adesão parcial, e não quase total, como com os autores que o inspiraram nas outras fases. (MOTTA, op. cit, p. 388)
} 
continuación de un conflicto; no es un acto impersonal, general y abstracto, expresión de intereses objetivos, coherentes, racionalmente justificables y generalizables, es decir, si se quiere, 'constitucionales', del ordenamiento. ${ }^{76}$

A exposição da tese do direito dúctil e a aproximação com as categorias teóricas poulantzianas tem também por escopo a demonstração de outro fenômeno relacionado: o aprofundamento das relações entre as lutas políticas e o aparelho de Estado. Este aprofundamento se dá através da interiorização/institucionalização das lutas a um aparelho específico (o judicial) que, na verdade, acaba refletindo uma abertura relativa do Estado às lutas políticas - daí o que se tem denominado atualmente de judicialização da política. 0 constitucionalista Luís Roberto Barroso ${ }^{77}$, ao comentar a ascensão política do Poder Judiciário especificamente no caso brasileiro, referiu que a judicialização da política é um fato que advém do próprio desenho institucional promovido pela Constituição (em específico a Constituição Federal de 1988):

No Brasil, o fenômeno assume uma proporção maior em razão de a Constituição cuidar de uma impressionante quantidade de temas. Incluir uma matéria na Constituição significa, de certa forma, retirá-la da política e trazê-la para o Direito, permitindo a judicialização.

Dessa forma, percebe-se que tal fenômeno decorre naturalmente da necessidade que o aparelho judicial tem de trabalhar com esta pluralidade de princípios, valores e normas. Nesse sentido, Nascimento indica que esta internalização promove uma complexificação da atuação do Judiciário, tendo em vista que:

Isso leva os juízes a trabalharem com valores constitucionalizados, mas muitas vezes de difícil aplicação, o que pode acarretar em decisões disfarçadas de real poder constituinte. A partir do que foi mencionado, é perceptível a dificuldade de se manter o equilíbrio das três funções estatais. ${ }^{78}$

Sobre isso, ainda, Barroso é preciso: “A despeito de algum grau de subversão ao princípio da separação de Poderes, trata-se de uma inevitabilidade, a ser debitada à complexidade e ao pluralismo da vida contemporânea".

\footnotetext{
${ }^{76}$ ZAGREBELSKY, op. cit., p. 38.

77 BARROSO, Luis R. A ascensão política das Supremas Cortes e do Judiciário. Revista Consultor Jurídico, 6 jun. 2012.

${ }^{78}$ Op. cit., p. 84.
} 
Diz-se, assim, que tal fenômeno caracteriza uma abertura "relativa” por que, apesar da flexibilização jurídica demonstrada, não é suficiente para dissolver o Estado em puro jogo das relações de força, já que o mesmo ainda mantém um grau de materialidade própria capaz de refratar os efeitos daquelas. Tal processo é, na verdade, permeado de tensões expressadas em vários níveis. A própria Constituição - mesmo com todas as transformações manifestadas em seu seio -, por exemplo, funciona por vezes como elemento limitador dos efeitos dessas relações ${ }^{79}$, mas também carrega um importante papel na luta pela garantia e conquista dos direitos fundamentais nela inscritos que muitas vezes se chocam com a realidade das formações sociais concretas. Ainda, outro exemplo desse tensionamento se dá entre a constatação teórica e o universo prático do direito. Apesar de Zagrebelsky explicitar de forma precisa as mudanças que se processam em relação ao paradigma positivista do Estado de direito, lembra que a ideia de direito que o atual Estado constitucional implica não entrou plenamente no ar que respiram os juristas ${ }^{80}$.

Todas as determinantes que envolvem os processos demonstrados, entretanto, não são capazes de serem esgotadas neste estudo, isso iria muito além do intuito proposto. A partir da aproximação entre esses desenvolvimentos teóricos no âmbito das teorias constitucional e política, pretendeu-se problematizar algumas questões referentes às transformações pela qual o Estado, o direito e a Constituição passaram nos últimos anos a fim de que sirvam como elementos agregadores à tentativa de compreensão do fenômeno constitucional contemporâneo e sua relação com as lutas políticas travadas no âmbito da sociedade civil organizada. Por corolário, cabe, neste intento, o constante desenvolvimento das ideias apresentadas e estudos desses fenômenos sob matizes diversos.

\section{CONCLUSÃO}

A história do constitucionalismo das democracias ocidentais carrega em si a marca da luta pela liberdade e, portanto, das lutas emancipatórias que se desenvolveram a partir das

\footnotetext{
${ }^{79}$ Isso Zagrebelsky já manifestara em algumas passagens de sua obra quando, por exemplo, refere que as orientações possíveis ao Estado ficam condicionadas ao "ámbito de las posibilidades ofrecidas por el compromiso constitucional" (op. cit., p. 13), ou que constituições "abertas" significam textos constitucionais que permitem a espontaneidade da vida social a competição da direção política dentro dos limites constitucionais (Ibid., p. 14).

${ }^{80}$ ZAGREBELSKY, op. cit., p. 10.
} 
diferentes acepções recebidas por este termo. Pode-se dizer assim que, fundamentado na teoria política liberal, o constitucionalismo compôs as bases do projeto emancipatório da modernidade, sendo essencial à conquista do rol de direitos que compõem a noção de cidadania civil e política. Num mesmo movimento, entretanto, teve papel fundamental na formação e cristalização de uma nova estrutura de Estado; na inauguração da estrutura jurídico-política que contribuiu para a sustentação de formações sociais calcadas nos ideário político da emergente burguesia e, consequentemente, na sua organização enquanto classe hegemônica.

As lutas populares, entretanto, revelaram aos poucos a possibilidade de 0 constitucionalismo assumir novos caracteres. Das tensões dialéticas criadas no seio da sociedade civil e das agitações políticas daí advindas, o constitucionalismo foi gradualmente moldado para receber novas categorias de direitos - tal é o momento em que revela não caracterizar um movimento de fim meramente instrumentalista, mas ser também produto da condensação material da relação de forças constante na estrutura social.

O fenômeno do neoconstitucionalismo representa a emergência de um novo paradigma estatal - o Estado constitucional -, enraizado nas transformações inseridas no interior das formações sociais concretas, que reflete consequências nos campos das teorias do Estado e do Direito, e significa, em último grau, uma maior abertura (não por isso unívoca, mas tensa em si) do Estado às lutas políticas. Esse novo paradigma é caracterizado pela internalização (e elevação à categoria de norma), através das atuais constituições, de princípios baseados no ideal de convivência pluralista, que fornecem maior legitimidade aos grupos sociais insertos na correlação de forças que compõem as formações sociais e o Estado (materialização dessa correlação) - é nesse sentido que se dá a abertura constitucional às lutas políticas, mostrando-se as atuais constituições verdadeiros compromissos com as possibilidades.

O constitucionalismo contemporâneo, portanto, ao contribuir para a relativa desestruturação daquele paradigma jurídico baseado em normas gerais, abstratas, $e$ estritamente regulamentadas, seria capaz de alargar as chances de desenvolvimento de práxis transformadoras; capaz de abrir espaços na estrutura jurídico-política para o desenvolvimento das relações de forças presentes na luta pela efetivação de direitos. Nesse sentido o neoconstitucionalismo abre portas às possíveis transformações sociais necessárias ao saneamento das tensões entre o real histórico e os recentes textos constitucionais (principalmente nos países periféricos e emergentes, como é o caso do Brasil com a Constituição Federal de 1988) e das tensões existentes nesses próprios textos. Tal é o momento em que se mostra um importante instrumento na incessante busca pela efetivação dos direitos fundamentais constantes nas cartas 
constitucionais - insere-se aqui uma concepção ampliada de cidadania, produto das conquistas dos movimentos sociais reivindicativos e da sociedade civil organizada.

\section{REFERÊNCIAS}

BARROSO, Luis R. A ascensão política das Supremas Cortes e do Judiciário. Revista Consultor Jurídico, 6 jun. 2012. Disponível em: <http://www.conjur.com.br/2012-jun-06/luis-robertobarroso-ascensao-politica-supremas-cortes-judiciario>. Acesso em: 10 jun. 2012.

BOBBIO, Norberto. Estado, governo, sociedade; para uma teoria geral da política. 12. ed., Rio de Janeiro: Paz e Terra, 2005a.

. Igualdade e liberdade. Rio de Janeiro: Ediouro, 1996.

. Liberalismo e democracia. 6. ed., São Paulo: Brasiliense, 2005b.

CANOTILHO, Joaquim J. G. O Estado adjetivado e Teoria da Constituição. Revista da Procuradoria-Geral do Estado, Porto Alegre, v. 25, nº 56, p. 25-40, dez 2002.

CARBONELL, Miguel. Nuevos Tiempos para el Constitucionalismo (Prólogo). In: Neoconstitucionalismo(s). 2. ed., Madrid: Editorial Trotta, 2005. (ed.).

. El Neoconstitucionalismo em su Laberinto (Presentación). In: (ed.). Teoría del neoconstitucionalismo; Ensayos escogidos. 2. ed., Madrid: Editorial Trotta, 2007.

JESSOP, Bob. O Estado, o poder o socialismo de Poulantzas como um clássico moderno. Rev. Sociol. Polít., Curitiba, v. 17, n. 33, p. 131-144, jun. 2009. Disponível em:

<http://www.scielo.br/pdf/rsocp/v17n33/v17n33a10.pdf>. Acesso em: 28 fev. 2012.

JULIOS-CAMPUZANO, Alfonso de. Constitucionalismo em tempos de globalização. Porto Alegre: Livraria do Advogado, 2009.

MATTEUCCI, Nicola. Constitucionalismo. In: BOBBIO, Norberto. MATTEUCCI, Nicola. PASQUINO, Gianfranco (org). Dicionário de Política. 11. ed., Brasília: Editora UnB, 1998. v. 1, p. 246-258.

MOTTA, Luiz Eduardo. Poulantzas e o Direito. DADOS - Revista de Ciências Sociais, Rio de Janeiro, Vol. 53, $n^{\circ} 2$, 2010, p. 367-403.

NASCIMENTO, Valéria Ribas do. O tempo das reconfigurações do constitucionalismo: os desafios para uma cultura cosmopolita. São Paulo: LTr, 2011.

PÉREZ-LUÑO, A. E. Perspectivas e tendências atuais do Estado Constitucional. Porto Alegre: Livraria do Advogado, 2012. 


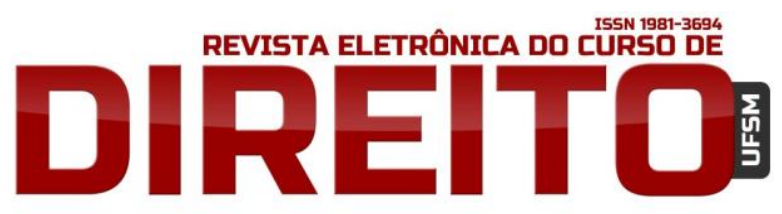

A CONSTITUIÇÃO ENTRE A REGULAÇÃO E A EMANCIPAÇÃO: o neoconstitucionalismo e a "ductilização" da estrutura jurídicopolítica do Estado

PINTO NETO, Moysés. A Matriz Oculta do Direito Moderno: crítica do constitucionalismo contemporâneo. Cadernos de Ética e Filosofia Política. $n^{\circ} 17$, São Paulo, $2^{\circ}$ semestre de 2010. Disponível em: <http://www.fflch.usp.br/df/cefp/Cefp17/neto.pdf>. Acesso em: 11 de agosto de 2012.

POULANTZAS, Nicos. O Estado, o poder, o socialismo. 4. ed., São Paulo: Graal, [1978] 2000.

SAES, Décio. A questão da autonomia relativa do Estado em Poulantzas. Revista Crítica Marxista, n.7, p. 46-66. São Paulo: Xamã, 1998. Versão eletrônica disponível em:

<http://www.unicamp.br/cemarx/criticamarxista/critica7parte3.pdf>. Acesso em: 29 out. 2012.

Cidadania e capitalismo: uma crítica à concepção liberal de cidadania. Revista Crítica Marxista, n.16, 2003. Disponível em:

<http://www.unicamp.br/cemarx/criticamarxista/16saes.pdf>. Acesso em: 29 out. 2012.

SANTOS, Boaventura de S. Subjetividade, cidadania e emancipação. In: Pela mão de Alice: o social e o político na pós-modenidade. 11. ed., São Paulo: Cortez, 2006. cap. 9, p. 235-280.

VALE, André R. do. Aspectos do neoconstitucionalismo. Revista Brasileira de Direito Constitucional (RBDC), n 9, jan./jul. 2007. São Paulo: ESDC, 2007. p. 67-77.

ZAGREBELSKY, Gustavo. El derecho dúctil; Ley, derecho, justicia. Traducción: Marina Gascón, 7. ed., Madrid: Editorial Trotta, 2007.

Recebido em: 30 abr. 2013

Revisões requeridas: 16 jun. 2013

Aprovado em: 08 jul. 2013 